\title{
INTEGRATION OF FIRE PROTECTION SYSTEMS BASED ON THE DIGITAL AUTOMATIC MODEL
}

\author{
K.M. Volkova, ksenifire@bk.ru \\ State Fire Academy of EMERCOM of Russia, Moscow, Russian Federation
}

\begin{abstract}
The development of refineries increases the number and scale of fires and accidents, which cause damage both to the facilities themselves and to the surrounding buildings and structures, lives and health of people, the environment. That is why increasing the level of fire protection systems at refineries remains one of the most important components of ensuring the protection of the population from anthropogenic threats.

The article presents the results of the analysis of accidents and fires at oil refineries (refinery) for 2015-2019. The issue of necessity to integrate fire protection system at the refinery is considered. The process of creation and functioning of the automated integrated fire protection management system is described in the article. This system is a new approach to solving the issue of safety of industrial facilities of oil refining industry. Creation of a new model of fire protection system based on digital automatic system is described. The article considers the scheme of generalized structure of digital automatic machine and graphs of digital automatic machine of automated integrated fire detection and monitoring system.

The developed technology makes it possible to process the incoming signal contained in cyclograms into an intermediate form for synthesis of digital automatic machines by means of innovative tools.
\end{abstract}

Keywords: fire protection, automated control system, digital automatic machine, detection and monitoring system.

\section{Introduction}

The oil refining industry plays an important role in the country's economy and at the same time carries a danger as a source of fire and man-made accidents. The development of oil refineries increases the number and scale of fires and accidents, which cause damage both to the objects itself and to the surrounding buildings and structures, lives and health of people, environment. That is why increasing the level of fire protection systems at refineries remains one of the most important components of ensuring the protection of the population from anthropogenic threats [1]. Accidents and fires at oil refineries (Refineries) are difficult conditions with a rapid spread of fire to nearby areas and vehicles, which most often turn into a catastrophe whose material damage is huge. Refinery fires can be significant because of the large volume of flammable and combustible liquids stored in the territory [1].

\section{Refinery accident and fire analysis}

According to the data, the number of fires and explosions at the refinery over the last 5 years has been analyzed. The analysis results show that the annual number of fires ranges from 30 to 50 . According to the analysis for 2015-2019, there were 186 fires (Fig. 1).

Refinery fires cause great material damage as expensive equipment, raw materials and communications cannot be restored. Fig. 2 shows that the average material damage from one fire is more than 1 million rubles, this value is much higher than the average damage from the total number of fires. Whereas, larger fires at refineries cause several times more damage. The average damage is the expected damage, i.e. more likely, and the maximum damage is the damage in the worst-case scenario. This large difference between the expected damage and the maximum damage makes it possible to conclude that refinery fire protection needs to be improved by integrating fire protection systems.

In order to effectively address the issue of integrating fire protection systems in refineries, it is necessary to understand the causes of fire. During the analysis the main interconnected groups of fire causes have been formed (Fig. 3). 


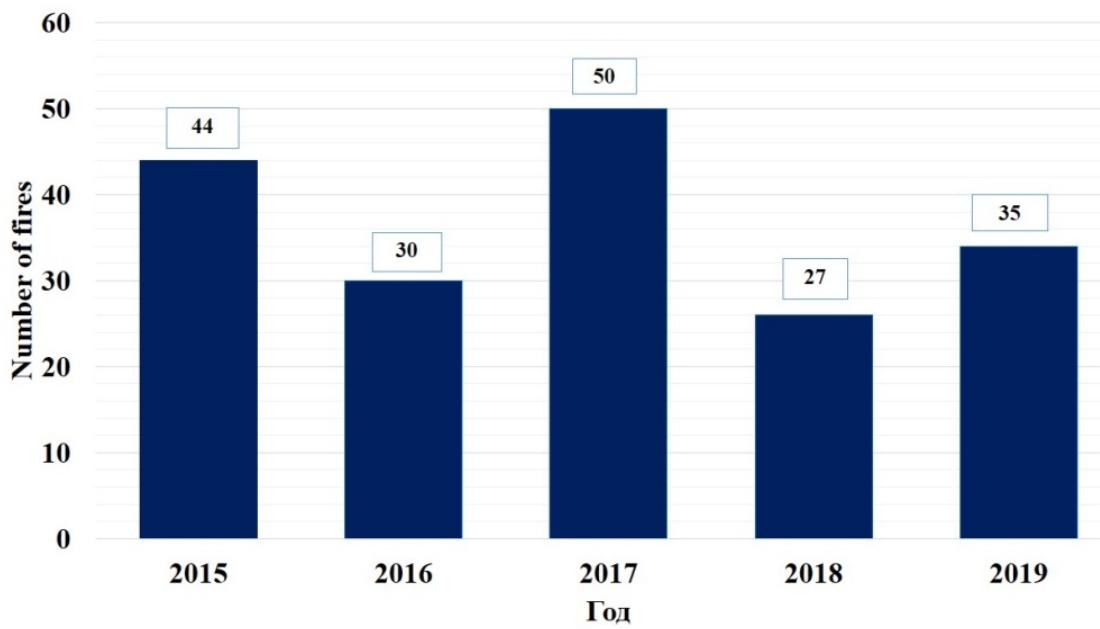

Fig. 1. Number of fires at oil refineries

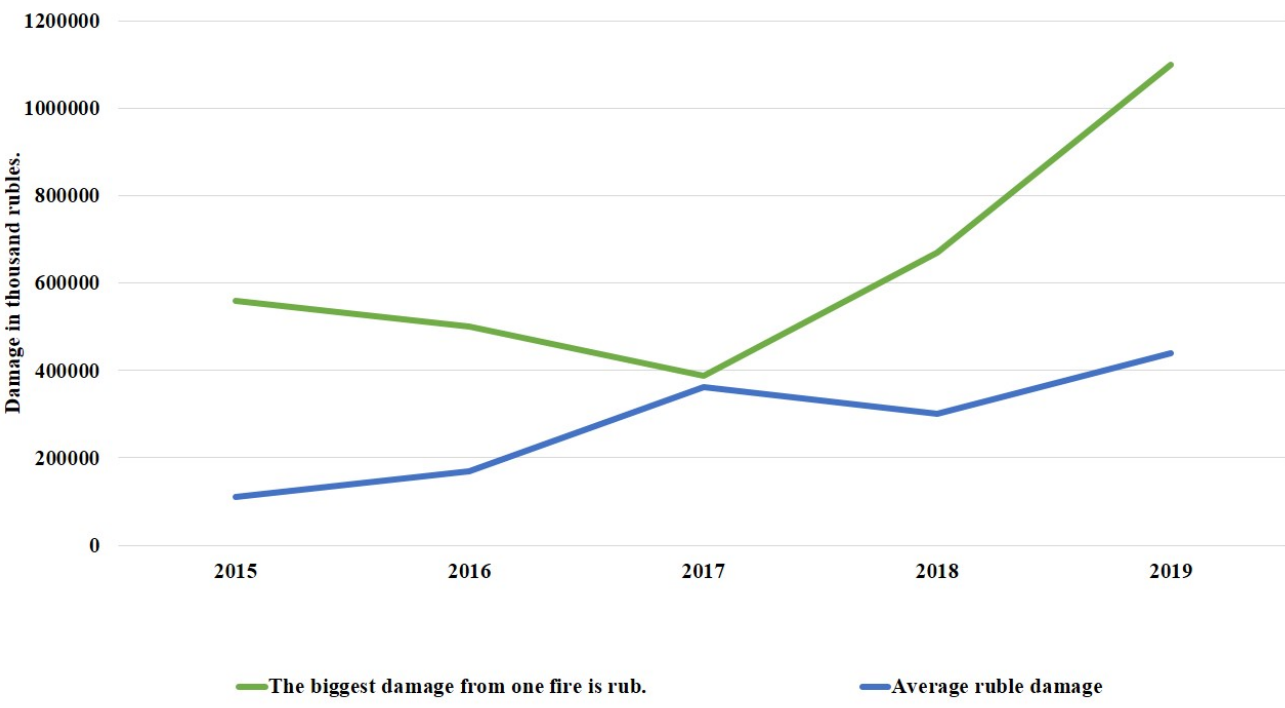

Fig. 2. Damage from fires at oil refineries

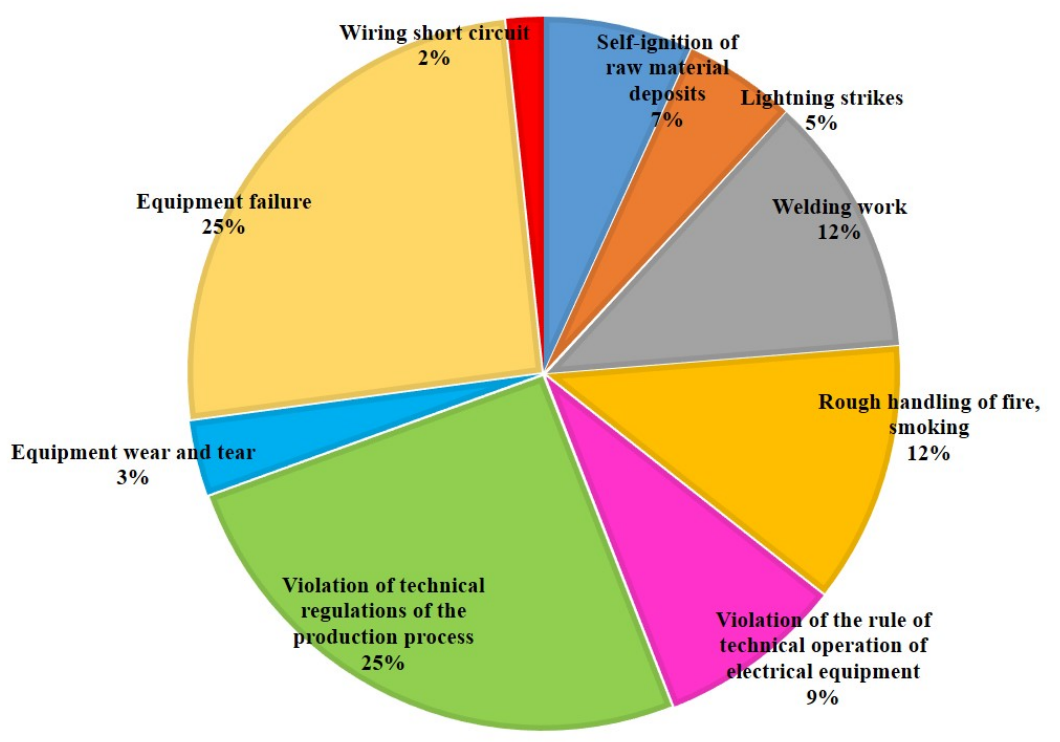

Fig. 3. Main causes of fires 
Based on the diagram of analysis of the main causes of fire, it can be concluded that the main ones are:

- emergency operation of the equipment;

- violation of the technological regulations of the production process.

Technological process of refinery is complicated, so it is necessary to control from the side of service personnel for the regulatory values of parameters and the timeliness of measures for localization and liquidation of emergency situations, as there is a possibility of output of parameters for critical values, depressurization of equipment (from partial to full) and release of hazardous substances [2]. Errors in transient modes (start and stop of equipment), at operations, at drainage, repair, preventive and other works connected with unstable modes, release and filling of equipment with hazardous substances represent special danger in technological process of refinery [2].

As a result, the analysis of reasons of origin of fires on refineries has defined, that all of them have essential feature: the reason of these fires, as a rule, the whole set of circumstances, each of which by itself could not initiate a large fire, and only their set can lead to scale consequences. In turn, the question on integration of system of fire-prevention protection of oil refining objects has matured.

Every year technological processes of refineries become more advanced, innovative technologies become more widespread, the process and organization of production in the majority is accompanied by the use of potentially dangerous technologies, and this has led to the complication of equipment and processes, as the provision of integrated safety of technical production at the enterprise includes automated integrated fire protection systems (AISPEZ). Automated integrated systems of fire detection and monitoring, fire extinguishing, evacuation and smoke removal play one of the main roles in the structure of technological processes of industrial facilities.

The development and distribution of these systems requires new solutions in the synthesis of their operation models. In the event of an emergency situation, fire, or fire at an industrial facility, an automated integrated fire detection and monitoring system (AISOMP) should immediately operate. For the purpose of demonstration of all cause-and-effect relations in AISOMP it will be rational to apply structural-functional models of the digital automatic machine (CA), with their help it is possible to minimize and exclude probability of errors at the further synthesis of the automatic machine project by means of the specialized software. Similarly, AISOMP will provide an opportunity to formalize the synthesis process of transitions and outputs functions, without which it is impossible to build CA models [3]. Thus, the main purpose of synthesis of the model of digital automaton and automated integrated fire detection system is to minimize and exclude the probability of errors arising from the improvement of methods of information transformation into AISOMP. The system based on the CA model is synthesized in a specialized design environment, such as Active-HDL. The model is built in a cyclogram, which displays the AISOMP cycle [4]. The system design algorithm according to the proposed integrated model is shown in Fig. 4.

According to a given cyclogram, structural-functional models of digital automata are designed, for which unified tables of transitions and outputs functions are compiled, and then a hierarchical system model of CA is designed.

The sequence of switching mechanisms on and off is determined by the technologist, and cause-effect relations between commands are indicated on the cyclogram. To start AISOMP it is necessary to carry out several of conditions of its occurrence: an emergency mode, a flame, smoke, collapse of building designs the received control information, it is necessary to transform to a logic signal convenient for working out of algorithms, and debugging of a program code of the controllers realised in the form of CA [5, 6].

In the structure of CA there is a transition graph. The transition graph has the following properties:

a) the graph does not contain parallel arcs;

b) there is one vertex in the set of vertices of the graph, which is called the input of the graph;

c) in the set of vertices of the graph one vertex, which is called the output of the graph, is selected;

d) each vertex of the graph reaches its output.

Fig. 5 shows the screen of the modeling panel of the digital machine, the working area of which is divided into two parts: the base of announcements and the working area in which the model CA is designed [7]. The declaration header includes the declaration of the automaton's input and output ports. The above functions of Active-HDL environment reduce the time-consuming design and verification of CA models for automated control devices. 


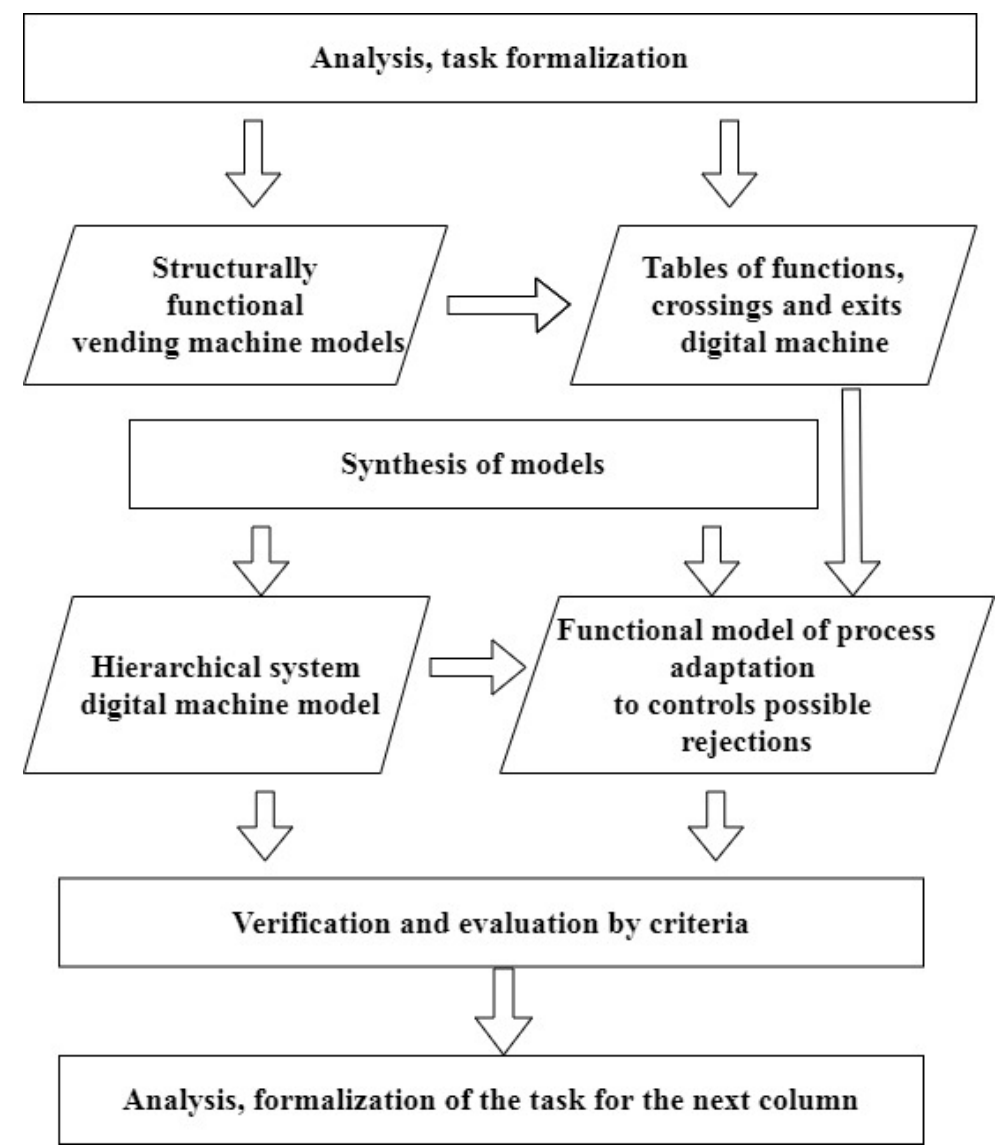

Fig. 4. Algorithm for designing the structural-functional model of AISOMP digital automata

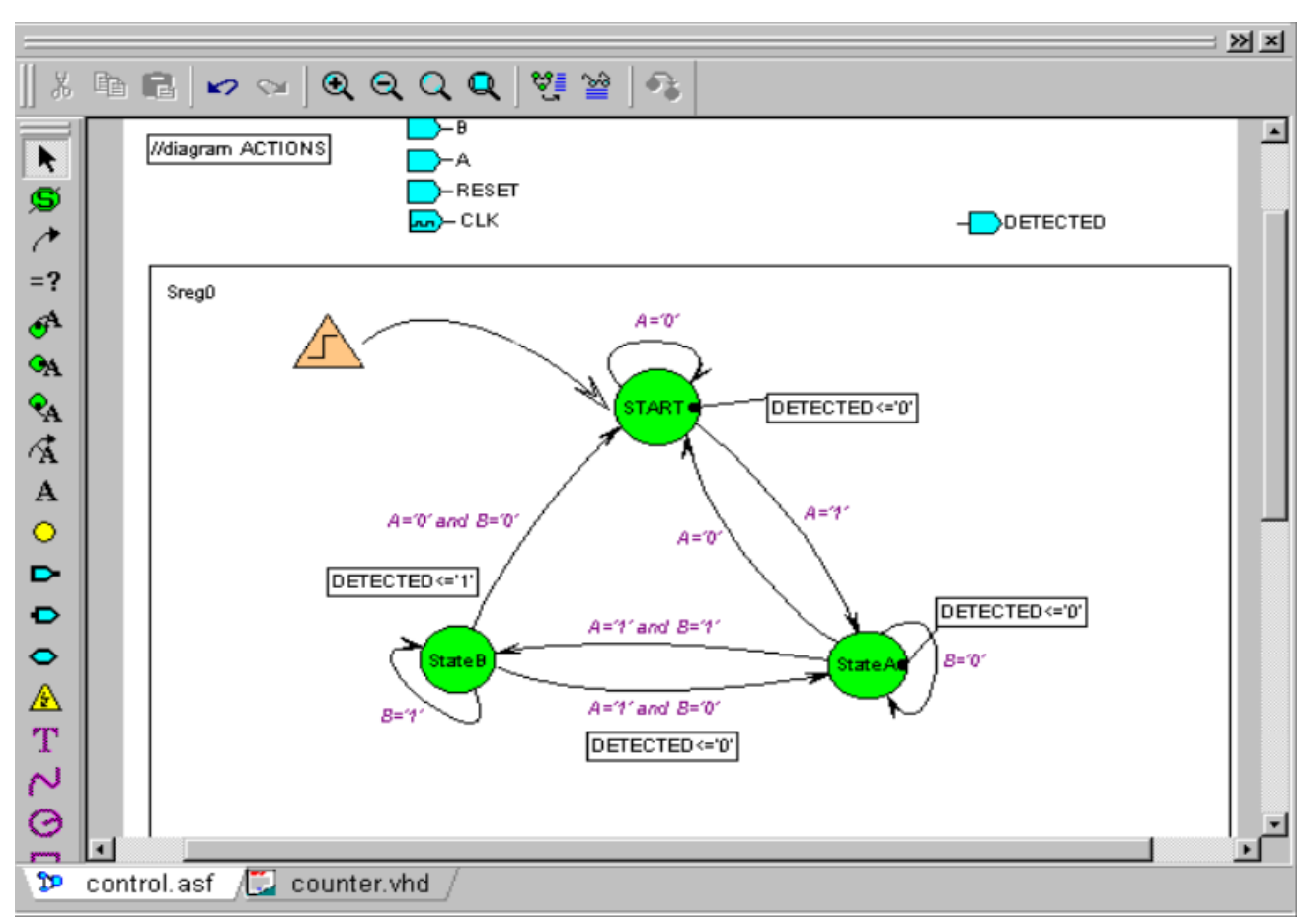

Fig. 5. Example of a digital machine model in Active-HDL environment

Using the State Diagram Editor allows you to automate the formation of HDL-code of the project, to verify it and select a promising control system. 
The incoming signal in the model of the AISPPPZ refinery digital automatic machine will pass through 4 stages before starting one of the systems to localize a fire or an accident. The synthesis of the digital automatic machine is divided into four stages (Fig. 6). They are called conditionally:

(a) The stage of block synthesis of the automatic machine - it is divided into separate blocks;

b) stage of abstract synthesis - the amount of memory consumed for the given block is determined;

c) the stage of structural synthesis, when there is a choice of logical and memory elements for building a block;

d) the stage of synthesis reliability - the conversion and addition of the schemes built to provide reliability is performed $[8,9]$.

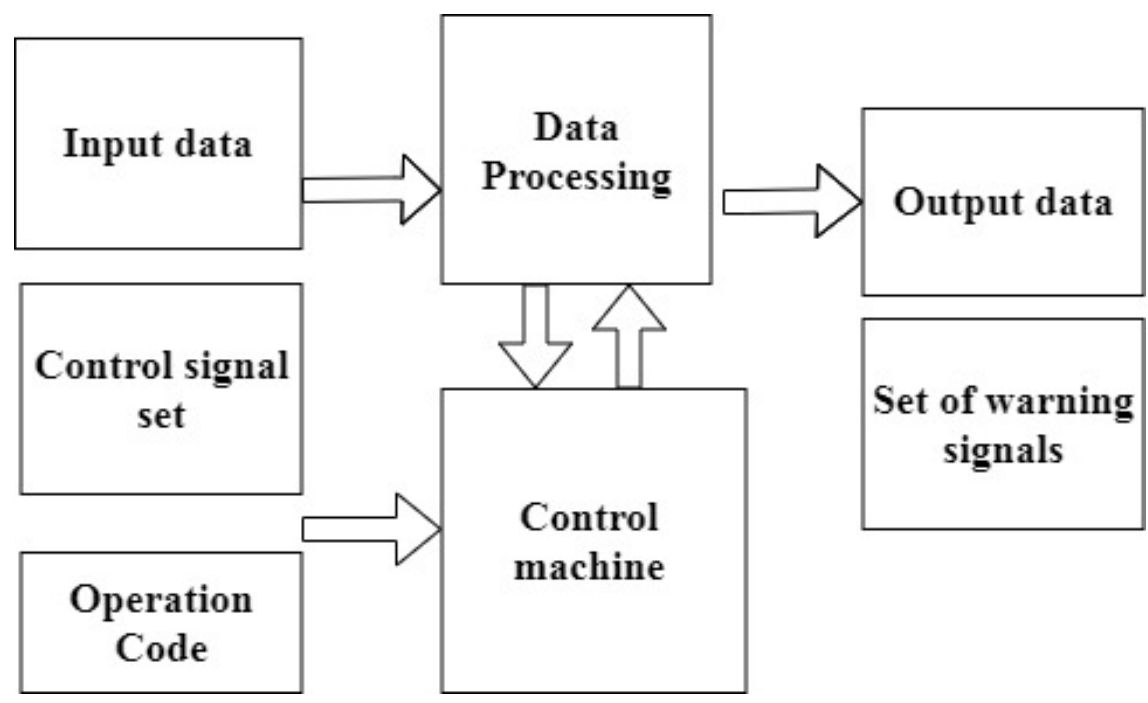

Fig. 6. CA model

Let's consider the model of CA AISOMP Refinery without taking into account the mechanics of this system. The device can be in several states:

1) $\mathrm{C} 1$ - AISOMP in the open state;

2) $\mathrm{C} 2$ - AISOMP in working process at signal transfer on AISOMP;

3) C3 - AISOMP in the open state after receiving the fire signal;

4) $\mathrm{C} 4$ - AISOMP is off.

Signals sent to the device: a signal about the flame (a1), a signal about the safe flame (technological process, for example, burning parts) (a0), a signal about dangerous fire (a2), a signal about the emergency situation (a3), a signal about security violation (a4), a signal about returning to the previous state (a5) [10-12].

The initial state is $\mathrm{C} 2$. If a flame occurs, the system will respond and signal a1, the state will change to C3. After identifying a fire as a fire, the system must change to the previous state with signal a2. In the case of a safe fire that does not need to be localized and the fire extinguishing system is started, the signal a0 will not change the state.

This device is connected to the general system of the enterprise and, in case of emergency, the signal will go to the AISP and AISE system to notify the refinery employees. In order to do so, the device must receive an a3 signal, and therefore the $\mathrm{C} 2$ status will be replaced by the $\mathrm{C} 1$ status. To ensure information protection of the refinery in case of arson, signal a4 should be sent to the unit. It will transfer the system from state $\mathrm{C} 2$ to state $\mathrm{C} 4$. The refinery security will have a5 signal, which will change state $\mathrm{C} 1 / \mathrm{C} 4$ to $\mathrm{C} 2$. For illustration let's consider the described examples in the form of graphs, in which the points "C" are the system state, arc "a" - transitions from these states (Fig. 7).

The problem of synthesis of the digital automatic machine for AISPPZ arises because there is no ready standard integrated circuit suitable for unity of work of AISPPZ refinery and reliability and simplicity of algorithm of work of model CA AISOMP solves this question. The model of the digital automatic machine for AISPPPZ refinery will be constructed of separate standard integrated schemes in Active-HDL program. As the whole AISPPZ system is complex, there is a necessity to create several CA algorithms which will work in one system [13-15]. 


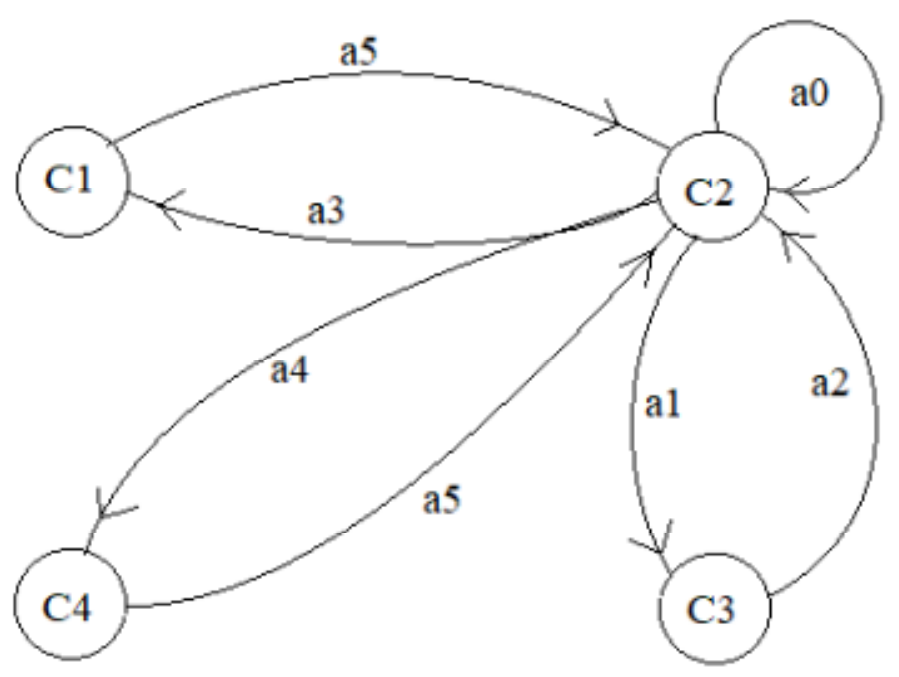

Fig. 7. The graph of CA AISOMP model states

\section{Conclusion}

Integration of the system based on the digital automat model will minimize and eliminate errors in the operation of the AFPZ. The advantage of the described model of the digital automatic machine is that it makes it possible to determine the required number of input signal states corresponding to control and monitoring operations. The developed technology makes it possible to process the incoming signal contained in cyclograms into an intermediate form for synthesis of digital automata using innovative tools.

\section{References}

1. Topolskiy N.G. [Problems and Principles of Creation of the Integrated Safety and Life Support Systems]. Proceedings of the fourth international conference "Informatization of safety systems", 1995, pp. 14-17. (in Russ.)

2. Kozlitin A.M., Yakovlev B.N. Chrezvychaynyye situatsii tekhnogennogo kharaktera. Prognozirovaniye $i$ otsenka. Determinirovannyye metody kolichestvennoy otsenki opasnostey tekhnosfery [Technogenic Emergencies. Prediction and Estimation. Determined Methods of Quantitative Assessment of Technosphere Hazards]. Saratov, Saratov State University, 2000. 124 p.

3. Entsiklopediya bezopasnosti [Encyclopedia of Safety]. Available at: http://protivpozhara.ru/tipologija/teorija/pozhary-i-vzryvy-na-vzryvopozharoopasnyx-obektax (accessed 01.03.2020).

4. Kotlyarovsky V.A., Zabegaev A.V. Avarii $i$ katastrofy. Preduprezhdeniye i likvidatsiya posledstviy [Accidents and Catastrophes. Prevention and Liquidation of Consequences]. Moscow, Publishing House of ASV, 1998. $416 \mathrm{p}$.

5. RD 03-418-01. Metodicheskiye ukazaniya po provedeniyu analiza riska opasnykh proizvodstvennykh ob"yektov [Methodical Guidelines for Risk Analysis of Hazardous Industrial Facilities]. Moscow, 2001. $25 \mathrm{p}$.

6. Prusenko B.E., Martyniuk V.F. Analiz avariy i neschastnykh sluchayev $v$ neftegazovom komplekse Rossii [Analysis of Accidents and Accidents in Oil and Gas Complex of Russia]. Moscow, Hazard Analysis LLC, 2002. 309 p.

7. CHP na neftepererabatyvayushchikh zavodakh v Rossii v 2008-2013 gg [PE at Oil Refineries in Russia in 2008-2013]. Available at: https://ria.ru/spravka/20130822/957868347.html (accessed 01.03.2020).

8. Zyubin V.E. Programmirovaniye informatsionno-upravlyayushchikh sistem na osnove konechnykh avtomatov [Programming of Information and Control Systems on the Basis of Finite Automata]. Novosibirsk, Novosibirsk State University, 2006. 96 p.

9. Shalyto A.A. [Automatic Programming]. Computer sciences and information technologies: theses of reports of International scientific conf. of memory of Prof. A.M. Bogomolov, 2007. 
10. Martinov G.M., Kozak N.V., Nezhmetdinov R.A. Implementation of Control for Peripheral Machine Equipment Based on the External Soft PLC Integrated with CNC. International Conference on Industrial Engineering. - Applications and Manufacturing (ICIEAM), 2017, p. 1-4.

11. Schaefer J., Polzin N., Sauter T., Dzierzawa G., Jung J., Kuehner B. 00 Système d'entraînement à l'emploi de l'ordinateur [Komp'yuternaya sistema obucheniya]. Patent EP 0690426 (A2), publ. 03.01.1996, G09B 19.

12. Cadossi R., Marazzi D. Contact detecting and signaling device [Ustroystvo obnaruzheniya $i$ signal'noye ustroystvo]. Patent EP 1111966 A, publ. 27.06.2001, Signaling Device, G08B 5/00.

13. Martinova L.I., Kozak N.V., Nezhmetdinov R.A. The Russian Multi-functional CNC System AxiOMA Control: Practical Aspects of Application Automation and Remote control, 2015, vol. 76, no. 1 , p. $179-186$.

14. Martinov G.M., Nezhmetdinov R.A., Kuliev A.U. Approach to Implementing HardwareIndependent Automatic Control Systems of Lathes and Lathe-milling CNC Machines. Russian Aeronautics, 2016, vol.59, no. 2, pp. 293-296.

15. Mori Masahiko, Fujishima Makotoб Oda Yohei. 5 Axis Mill Turn and Hybrid Machining for Advanced Application. Procedia CIRP 1, 2012, pp. 22-27. DOI: 10.1016/j.procir.2012.04.004

Received 25 April 2020

УДК 519.713

DOI: $10.14529 / \mathrm{ctcr} 200304$

\section{ИНТЕГРИРОВАНИЕ СИСТЕМ ПРОТИВОПОЖАРНОЙ ЗАЩИТЫ НА ОСНОВЕ МОДЕЛИ ЦИФРОВОГО АВТОМАТА}

\section{К.М. Волкова}

Академия государственной противопожарной службы МЧС России, г. Москва, Россия

Развитие нефтеперерабатывающих заводов увеличивает количество и масштабы пожаров и аварий, которые наносят ущерб как самим объектам, так и окружающим зданиям и сооружениям, жизням и здоровью людей, окружающей среде. Именно поэтому повышение уровня систем противопожарной защиты НПЗ остается одной из важнейших составных частей обеспечения защиты населения от угроз техногенного характера.

В статье приводятся результаты анализа аварий и пожаров на нефтеперерабатывающих заводах (НПЗ) за 2015-2019 гг. Рассмотрен вопрос необходимости интегрирования системы противопожарной защиты на НПЗ. В статье изложен процесс создания и функционирования автоматизированной интегрированной системы управления противопожарной защитой (АИСУПЗ). Данная система является новым подходом к решению вопроса безопасности промышленных объектов нефтеперерабатывающей отрасли. Описывается создание новой модели системы противопожарной зашиты на основе цифрового автомата. В статье рассматривается схема обобщённой структуры цифрового автомата и граф цифрового автомата автоматизированной интегрированной системы обнаружения и мониторинга пожара.

Разработанная технология дает возможность обработки поступающего сигнала, содержащегося на циклограммах, в промежуточную форму для синтеза цифровых автоматов при помощи инновационных инструментальных средств.

Ключевые слова: противопожарная защита, автоматизированная система управления, ичифровой автомат, система обнаружения и мониторинга.

\section{Лuтература}

1. Топольский, Н.Г. Проблемы и принципы создания интегрированных систем безопасности и жизнеобеспечения / Н.Г. Топольский // Материаль четвертой международной конференции «Информатизаџия систем безопасности» - ИСБ-95. - М.: ВИПТШ МВД РФ, 1995. - С. 14-17. 


\section{Управление в технических системах}

2. Козлитин, А.М. Чрезвычайные ситуации техногенного характера. Прогнозирование и оценка. Детерминированные методы количественной оценки опасностей техносферы: учебное пособие / А.М. Козлитин, Б.Н. Яковлев; под ред. А.И.Попова. - Саратов: Сарат. гос. ун-т, 2000. - 124 c.

3. Против пожара: энциклопедия безопасности. - http://protivpozhara.ru/tipologija/teorija/pozhary-i-vzryvy-na-vzryvopozharoopasnyx-obektax.

4. Аварии и катастрофы. Предупреждение и ликвидация последствий: учеб. пособие. Книга 3. / под ред. В.А. Котляревского, А.В. Забегаева. - М.; Изд-во АСВ, 1998 - 416 с.

5. Методические указания по проведению анализа риска опасных производственных объектов: РД 03-418-01. - введ. 01.10.2001. - М.: 2001. - 25 c.

6. Прусенко Б.Е. Анализ аварий и несчастных случаев в нефтегазовом комплексе России: учебное пособие / Б.Е. Прусенко, В.Ф. Мартынюк; под ред. Б.Е. Прусенко, В.Ф.Мартынюка. - М.: ООО «Анализ опасностей», 2002. - 309 c.

7. ЧП на нефтеперерабатываюших заводах в России в 2008-2013 г2. // РИА новости. Россия сегодня. - https://ria.ru/spravka/20130822/957868347.html.

8. Зюбин, В.Е. Программирование информачионно-управляющих систем на основе конечных автоматов: учеб.-метод. пособие / В.Е. Зюбин. - Новосибирск: Новосибирский государственный университет, 2006. - 96 c.

9. Шалыто, А.А. Автоматное программирование / А.А. Шалыто // Компьютерные науки и информационные технологии: тезисы докладов Междунар. науч. конф. памяти проф. А.М. Богомолова. - Саратов: Саратовский государственный университет, 2007.

10. Martinov, G.M. Implementation of Control for Peripheral Machine Equipment Based on the External Soft PLC Integrated with CNC / G.M. Martinov, N.V. Kozak, R.A. Nezhmetdinov // 2017 International Conference on Industrial Engineering. - Applications and Manufacturing (ICIEAM), 1619 May. - 2017. - P. 1-4.

11. Patent EP 0690426 (A2), kl. G09B 19/00. Système d'entraînement à l'emploi de l'ordinateur / J. Schaefer, N. Polzin, T. Sauter, G. Dzierzawa, J. Jung, B. Kuehner. -03.01.1996.

12. Patent EP 1111966 A, G08B 5/00. Signaling Device / R. Cadossi, D. Marazzi. - 27.06.2001.

13. Martinova, L.I. The Russian multi-functional CNC system AxiOMA control: Practical aspects of application / L.I. Martinova, N.V.Kozak, R.A. Nezhmetdinov // Automation and remote control. 2015. - Vol. 76, no. 1. - P. 179-186.

14. Martinov, G.M. Approach to implementing hardware-independent automatic control systems of lathes and lathe-milling CNC machines / G.M. Martinov, R.A. Nezhmetdinov, A.U. Kuliev // Izv.Vuz. Av. Tekhnika. - 2016. - No. 2. - P. 128-131.

15. Mori, M. 5 axis mill turn and hybrid machining for advanced application / M. Mori, M. Fujishima, O. Yohei // Procedia CIRP. - 2012. - Vol. 1. - P. 22-27.

Волкова Ксения Михайловна, адьюнкт факультета подготовки научно-педагогических кадров, Академия государственной противопожарной службы МЧС России, г. Москва; ksenifire@bk.ru.

Поступила в редакцию 25 апреля 2020 г.

\section{ОБРАЗЕЦ ЦИТИРОВАНИЯ}

Volkova, K.M. Integration of Fire Protection Systems Based on the Digital Automatic Model / K.M. Volkova // Вестник ЮУрГУ. Серия «Компьютерные технологии, управление, радиоэлектроника». - 2020. T. 20, № 3. - C. 39-46. DOI: $10.14529 /$ ctcr200304

\section{FOR CITATION}

Volkova K.M. Integration of Fire Protection Systems Based on the Digital Automatic Model. Bulletin of the South Ural State University. Ser. Computer Technologies, Automatic Control, Radio Electronics, 2020, vol. 20, no. 3, pp. 39-46. DOI: $10.14529 /$ ctcr200304 